Article

\title{
Does Firm Performance Influence Corporate Social Responsibility Reporting of Chinese Listed Companies?
}

\author{
Muhammad Safdar Sial ${ }^{1, *}$, Chunmei Zheng ${ }^{1}$, Nguyen Vinh Khuong ${ }^{2}{ }^{(\mathbb{D})}$, Tehmina Khan ${ }^{3}$ \\ and Muhammad Usman ${ }^{4}$ \\ 1 School of Economics and Management of Wuhan University, Wuhan 430072, China; meiz6523@whu.edu.cn \\ 2 Faculty of Accounting and Auditing, University of Economics and Law, Viet Nam National University, \\ Ho Chi Minh City 700000, Vietnam; khuongnguyenktkt@gmail.com \\ 3 School of Accounting, RMIT University, Melbourne 3000, Australia; tehmina.khan@rmit.edu.au \\ 4 School of Management, Xi'an Jiaotong University, Xi'an 710049, China; musmanms14@gmail.com \\ * Correspondence: Safdar.sial786@gmail.com; Tel.: +86-159-2752-4240
}

Received: 23 May 2018; Accepted: 23 June 2018; Published: 28 June 2018

\begin{abstract}
This study aims to investigate whether firm performance influences corporate social responsibility reporting of Chinese listed companies. We have used the sample of all A-share listed firms on Shenzhen and Shanghai stock exchanges for the period 2008 to 2015. The authors used pooled ordinary least squares (OLS) regression as a baseline methodology. To control the possible problem of endogeneity we use one year lagged and two-stage least squares regression. We find that firm performance has a statistically significant impact on CSR reporting. Moreover, we see that firms with high performance are more likely to report CSR activities than low-performance firms. Additionally, five of the control variables (board size, CEO power, SOE, firm size, and Big4) have some influence on CSR reporting. These findings hold for a set of robustness tests. Our results have implications for the development of CSR reporting in developing countries like China. Our research suggests that, in China, companies with better financial performance undertake more CSR reporting. The paper contributes to the existing literature by investigating the effect of firm performance on CSR reporting of Chinese listed companies. Additionally, this paper enriches the current literature on CSR reporting and highlights the importance of a firm's financial performance for better environmental performance and reporting.
\end{abstract}

Keywords: corporate social responsibility; firm performance; stakeholder theory; slack resources theory; legitimacy theory; China

\section{Introduction}

In the last three decades, CSR reporting has received considerable attention. CSR reporting decreases the information gap between stakeholders and the firm, which leads to the minimization of the cost of capital [1] and increase in firm value [2,3]. Additionally, it provides a mechanism through which a company can improve its reputation [4].

We have investigated the effect of firm performance on corporate social responsibility (CSR) reporting through the lens of the stakeholder, slack resources, and legitimacy theories, expanding on prior literature [5-10]. The results of all these investigations are mixed. Economic benefits for shareholders has been a conventional consideration in economically developed and developing countries $[9,11]$. More research is called for in the context of economically developing countries, such as China $[5,7,8]$. 
It is essential to grasp the factors that influence a company's decision to report CSR information. Stakeholders and investors rely on this information to assess the CSR reporting of the firm. Previous studies have examined the numerous characteristics of corporate governance, such as leverage and size of the firm [12-14] and their impact on CSR reporting. Financial performance remains a key variable which impacts CSR performance and reporting. The impact of this variable was tested in the context of voluntary CSR reporting by Chinese companies. Chinese companies have been selected as China is the largest exporter in the world and the country also has the largest share of $\mathrm{CO}_{2}$ emissions in the world (Union of Concerned Scientists Cambridge, USA 2017). As a result, corporate social responsibility, which covers environmental impacts of business activities, needs to be a key consideration, requiring detailed analysis.

The main aim of reporting CSR related activities is to provide the necessary information that will affect the perception of society and stakeholders about the firm and its management [15]. The challenge for the firm is not only reporting the CSR activities, but also managing the perception of the stakeholders about CSR reporting [16]. In China, the government is the basic driver of corporate social responsibility, as most companies are state-owned [17,18]. The Chinese economy is described as a new and transitional economy with unique characteristics that are diverse from those of Anglo-Saxon countries. As a result, the factors which impact CSR in China are also different from influencing factors in other countries.

Regardless of where a company is based, traditionally, the motivation has been to maximize financial wealth [19] while ignoring factors, such as environmental impacts. However, today business has multiple stakeholders who have social and environmental expectations about business performance. Stakeholder theory posits that firms need to address stakeholder expectations [20]. Meeting stakeholder expectations requires financial resources. Slack resource theory highlights that firms with higher profitability undertake greater CSR action and reporting [21,22]. CSR reporting is a strategy for managing societal perceptions regarding social and environmental impacts [12,23]. Although the Chinese Central Government has been actively promoting the importance of CSR to enterprises and urging them to implement CSR practices [24], CSR reporting is still in the initial stage for Chinese companies [25]. As a result, various corporation-related factors have an impact on the amount of CSR reporting undertaken by Chinese companies. For example, Chinese firms focus on profitability when deciding to report CSR activities due to the lack of regulation and stakeholder influence [9] to the same degree as that found, for example, in European countries.

In our study, the CSR reporting index is considering as the dependent variable, and our research is based on a sample of 4257 firm-year observations. The observation period covers the years from 2008 to 2015. We find that average firm performance positively correlated to CSR reporting and, furthermore, better-performing firms demonstrate extra anticipation of reporting CSR information than the worse-performing firms. Our results remain consistent after controlling for endogeneity issues.

This study contributes to the literature in two ways. First, most studies have focused on the CSR impact on firm performance FP $[5,7,8]$. We investigate the effect of firm performance on CSR reporting $[9,26,27]$. Second, most studies have considered economically-developed countries [28,29]. Other countries, with different organizational factors, such as culture and control (influence through ownership), may have different perspectives and expectations for CSR issues. Our focus is on China, which is the largest $\mathrm{CO}_{2}$ emitter in the world [30].

The rest of the study organized as follows: Section 2 represents the literature review and research hypotheses; Section 3 explains the methodology; Section 4 represent the results and, finally, Section 5 represents the conclusion.

\section{Literature Review and Research Hypotheses}

Traditionally, the essential motivation behind firms has been to minimize agency cost and maximize stockholder wealth by meeting profit maximization expectations of investors [19]. However, today, firms work internationally, where they also likewise make contracts with 
moneylenders, clients, and suppliers with diverse social and environmental policies. Thus, companies must satisfy the social and environmental policies, as well as broader stakeholder expectations. Stakeholder theory posits that long-term survival of a firm depends on tending to the issues of stakeholders and, in this scenario, CSR is expanded to include business commitments to the public and stakeholders [20]. According to slack resource theory, higher levels of a firm's profitability foster the individual firms to report more CSR activities. Therefore, the firm's original behavior towards CSR reporting depends on the availability of surplus economic resources. Better firm performance is, therefore, more likely to lead to surplus financial resources [22], which can provide the firm with a chance to invest more in CSR-related activities, whereas a lower economic performance might lead to decreased CSR-associated activities [21].

As per the legitimacy perspective, better-performing firms need to show their commitments to community and social interest and deliver comprehensive report more fully on CSR activities to avoid regulations [31,32]. It is due to the availability of financial resources that firms would undertake more CSR performance and CSR reporting. The proponents of legitimacy theory perceive CSR information as the strategy for managing the perceptions of society regarding the social and environmental impact of business operations [23]. However, the current evidence is mixed. Roberts [33], Haniffa and Cooke [34], and Alnajjar [35] confirm a positive, and Neu and Warsame [36], establish a negative relationship, while Reverte [14] and Cormier and Magnan [13] have not obtained any noteworthy association between firm performance and CSR reporting. These different results are due to institutional and cultural differences between countries [12]. Chinese firms primarily consider profitability when deciding to report CSR activities due to a lack of regulatory costs and influence from stakeholders [9]. Therefore, when the company has good performance results, this motivates and encourages the implementation of CSR reporting.

According to Jamali [11], in the developed market, creating the most significant benefit for shareholders is a top priority, measured through business performance. $\mathrm{Zu}$ and Song [27], by using the survey method, showed that managers also looked at performance before considering the level of CSR disclosure. However, this will differ in the economy between developed and emerging markets [9]. Therefore, more research is needed to confirm this relationship $[5,7,8]$.

Ghelli [37] investigated the association between the disclosure of corporate social responsibility and firm performance. The sample included 322 Fortune 500 companies, and the author collected the firm performance information from the ORBIT database and information related to CSR was collected from the KLD database. The findings proved the positive and significant association of CSR with Tobin's $Q$ and ROA. Nevertheless, ROE was not found to be significantly associated with CSR reporting.

Haniffa and Cooke (2005) found that firms with good performance lead to more information relating to CSR to legitimize their existence. The positive association between firm performance and CSR reporting is due to management opportunities and suppleness to issue circulation of more CSR activities to stockholders. Gamerschlag and Möller [38] found a positive association between firm performance and disclosures related to the environment. Tagesson and Blank [39] found that if the firm has good financial performance, there is a positive association between CSR reporting and the firm's financial performance, and firms can bear the cost of CSR reporting.

$\mathrm{Li}$ and Luo [9] investigated the nexus between firm performance and CSR information of listed firms in China in the year 2008. The sample data was 1574 non-financial listed firms from the China Stock Market and Accounting Research (CSMAR) database. CSR information was collected from the Bluebook of CSR reporting in 2009. ROA was used as a proxy of firm performance. The results confirmed that firms with a better return on assets led to better quality CSR reporting. A positive FP and CSR relationship suggest that CSR commitment generates the condition of preparing reports which meet the needs of stakeholders even if there is no substantial improvement in CSR commitment and performance (reputational value and return clients). According to Jiraporn and Jumreornvong [40] older companies with stable performance more aggressively participate in the CSR activities in which 
there is a focus on environmental performance. Our research builds on Li et al.'s work by considering a larger sample of Chinese companies and by covering a larger time frame from 2008 to 2015.

Based on the above discussion, we contend a positive association between firm performance and CSR reporting among Chinese firms.

Hypothesis (H1): Firm performance has a positive effect on CSR reporting.

Hypothesis (H2): High performing firms have a positive effect on CSR reporting than low performing firms.

\section{Methodology}

\subsection{Sample}

Our initial sample consisted of A-share listed firms on the Shenzhen and Shanghai stock exchanges. We collected data from the China Stock Market and Accounting Research (CSMAR) database for the period 2008 to 2015 for all variables. After dropping the observations with missing values, our final sample was reduced to 4257 firm-year observations.

\subsection{Measuring CSR}

In our paper, CSR reporting is the dependent variable. We have collected the data from CSMAR database to measure CSR reporting. We developed the CSR reporting index by using a dichotomous procedure: one if an item was reported and 0 if it not [34,41,42]. The total score of CSR reporting has been computed as follows. (please see Table 1 for details of the CSR reporting items):

Table 1. Corporate Social Responsibility Reporting Index.

\begin{tabular}{llc}
\hline & \multicolumn{1}{c}{ CSR Reporting Items } & Binary Scale \\
\hline 1 & Referring to GRI Sustainability Reporting Guideline or Not & 1.0 \\
2 & Reporting Protection of Shareholder Interests or Not & 1.0 \\
3 & Reporting Protection of Creditor Interests or Not & 1.0 \\
4 & Reporting Protection of Employee Interests or Not & 1.0 \\
4 & Reporting Protection of Supplier Interests or Not & 1.0 \\
6 & Reporting Protection of Interests of Clients and Consumers or Not & 1.0 \\
7 & Reporting Environment and Sustainability or Not & 1.0 \\
8 & Reporting Public Relations and Social \& Public Welfare or Not & 1.0 \\
9 & Reporting Social Responsibility System Construction and Improvement or Not & 1.0 \\
10 & Reporting Secure Production or Not & 1.0 \\
11 & Reporting Deficiencies of Company or Not & 1.0 \\
\hline
\end{tabular}

The total score of CSR Reporting has been computed based on the following formula: $\sum_{n}^{1} \frac{\mathrm{x}}{\mathrm{n}} \times 100$, where $\mathrm{x}$ equals to 1 if the item is reported, otherwise 0 and $n$ represent the number of all items.

\subsection{Measuring Firm Performance}

In our paper, firm performance is the independent variable, measured by Tobin's Q [43]. We measure Tobin's $Q$ as (market capitalization of total assets minus equity book value minus deferred tax liability divided by total assets).

\subsection{Measuring Control Variables}

Following a previous study [40], we added the following control variables: board size (B.Size, total number of directors on the board), CEO duality (CEO.D, 1, if the CEO and Chair are the same person, otherwise 0$)$, board member meeting frequency $(B M M F$, total number of board meetings held in one year), state-owned enterprises (SOE, a dichotomous variable equal 1, if the state or government control firm), firm age (Age, total number of listing years on the stock market), firm size (Size, total assets natural log ), leverage (Lev, proportion of total debt to total assets), and Big4 (Big4, a dichotomous variable equals 1 , if a big four firm audited firm reports). 


\subsection{The Model}

To investigate the effect of firm performance on CSR reporting, we estimated Equation (1), in line with a prior study [44], we use pooled ordinary least squares (OLS). To check the effect of high-performing firms on CSR reporting, we estimated Equation (2):

$$
\begin{gathered}
C S R_{i t}=\beta_{0}+\beta_{1} F P_{i t}+\sum_{i=1}^{n} \beta_{n} C V_{i t}+\varepsilon_{i t} \\
C S R_{i t}=\beta_{0}+\beta_{1} H P F_{i t}+\sum_{i=1}^{n} \beta_{n} C V_{i t}+\varepsilon_{i t}
\end{gathered}
$$

CSR refers to corporate social responsibility reporting, and FP represents firm performance (TQ). $H P F$ refer to high-performing firms. $C V_{i t}$ refers to all control variables (board size, CEO duality, board member meeting frequency, state-owned enterprises, firm age, firm size, leverage, Big4).

\subsection{Endogeneity}

We used two models to control the issue of endogeneity. First, we used the one year lagged measure of firm performance because firm performance needs time before having an effect on CSR reporting. Secondly, we used two-stage least squares (TSLS) regression to address endogeneity and used a one year lagged measure of firm performance as an instrumental variable.

\section{Results}

\subsection{Descriptive Statistics}

Descriptive statistics are presented in Table 2. The mean value of CSR reporting is 0.7319 with a standard deviation 0.1480 . The average value of firm performance is 2.354 with a standard deviation of 1.992. An average of nine board number exists in Chinese companies with a standard deviation 2.309. Furthermore, CEO power is $17 \%$; this means $83 \%$ of the firms have separated the position of CEO and Chairman on the board and the average number of the board meetings (BMMF) is about ten per year. The mean value of SOE is 0.59 ; this means $60 \%$ of Chinese companies are state-owned enterprises. The mean value of firm age is 11 years, and the average value of firm size is 23 . The mean value of leverage is about 0.5098. Finally, the mean value of Big4 is 0.16 (for details see Table 2).

Table 2. Descriptive statistics.

\begin{tabular}{cccc}
\hline Variable & Obs & Mean & Std. Dev. \\
\hline CSR & 4257 & 0.7319 & 0.148 \\
$F P(T Q)$ & 4257 & 2.354 & 1.992 \\
$H F P(T Q)$ & 4257 & 3.426 & 2.363 \\
LFP(TQ) & 4257 & 1.283 & 0.2344 \\
$B S$ & 4257 & 9.545 & 2.309 \\
CEOP & 4257 & 0.1797 & 0.3839 \\
BMMF & 4257 & 9.966 & 4.441 \\
SOE & 4257 & 0.5998 & 0.4899 \\
FA & 4257 & 11.583 & 5.634 \\
FS & 4257 & 23.07 & 1.749 \\
Lev & 4257 & 0.5098 & 0.2168 \\
Big4 & 4257 & 0.1654 & 0.3715 \\
\hline
\end{tabular}

CSR reporting is measured by CSR index by using a dichotomous procedure, one if an item disclosed, and 0 if it not. Firm performance is measured by Tobin's $Q$ (market capitalization of total assets minus equity book value minus deferred tax liability divided by total assets); board size (BS, the total number of directors on the board); CEO power $(C E O P, 1$, if $C E O$ and Chair are the same person, otherwise 0$)$; board member meeting frequency (BMMF, the total number of board meetings held in one year); state-owned enterprises ( $S O E$, a dichotomous variable equal to 1 , if the state or government controlled firm); firm age ( $F A$, the total number of listing years on the stock market); firm size (FS, total assets natural log); leverage (Lev, the proportion of total debt to total assets); Big4 (Big4, a dichotomous variable equals 1 if a big four firm audited firm reports). 


\subsection{Correlation Analysis}

Table 3 represents the Pearson correlation analysis. According to Gujarati [45], when the coefficient of correlation between independent variables is greater than 0.80 , there is a strong problem of multicollinearity. In our paper the correlation coefficient ranges from 0.0125 to 0.59 . Table 3 suggests that no strong multicollinearity problem would affect the results. Additionally, variance inflationary factor (VIF) did not exceed the limit of 3, and maximum correlation among the variables also remained less than 0.80 .

Table 3. Pearson correlation.

\begin{tabular}{|c|c|c|c|c|c|c|c|c|c|c|}
\hline & 1 & 2 & 3 & 4 & 5 & 6 & 7 & 8 & 9 & 10 \\
\hline 1-CSR & 1 & & & & & & & & & \\
\hline $2-F P(T Q)$ & $0.0125^{* * *}$ & 1 & & & & & & & & \\
\hline $3-B S$ & $0.1108^{* * *}$ & $-0.1964^{* * *}$ & 1 & & & & & & & \\
\hline 4-СЕОР & $-0.0693^{* * *}$ & $0.1436^{* * *}$ & $-0.1416^{*}$ & 1 & & & & & & \\
\hline 5-BMMF & $0.0437^{* * *}$ & $-0.0469^{* * *}$ & 0.0235 & -0.0127 & 1 & & & & & \\
\hline $6-S O E$ & $0.0770^{* * *}$ & $-0.2049^{* * *}$ & $0.1937^{* * *}$ & $-0.2309^{* * *}$ & $-0.0722^{* * *}$ & 1 & & & & \\
\hline 7-FA & $0.0952 * * *$ & $-0.1644^{* *}$ & $0.0409^{* * *}$ & $-0.1278^{* * *}$ & $0.0616^{* * *}$ & $0.3133^{* *}$ & 1 & & & \\
\hline 8-FS & $0.2217^{* * *}$ & $-0.3938^{* * *}$ & $0.4456^{* * *}$ & $-0.1328^{* * *}$ & $0.1704^{* *}$ & $0.2912 *$ & $0.1894^{* *}$ & 1 & & \\
\hline 9-Lev & $0.1314^{* * *}$ & $-0.4143^{* *}$ & $0.2577^{* * *}$ & $-0.1254^{* *}$ & $0.1920^{* * *}$ & $0.2129 * *$ & $0.2620 * * *$ & 0.595 * & 1 & \\
\hline 10-Big4 & $0.1409 * * *$ & $-0.1479^{* *}$ & $0.2649^{* * *}$ & $-0.0799 * *$ & $0.0612^{* *}$ & 0.1674 * & $0.0298^{* * *}$ & $0.546^{*}$ & 0.227 * & 1 \\
\hline
\end{tabular}

CSR reporting measured by the CSR index by using a dichotomous procedure, one if an item disclosed and 0 if it not. Firm performance measured by Tobin's $Q$ (market capitalization of total assets minus equity book value minus deferred tax liability divided by total assets). Board size (BS, the total number of directors on the board). CEO power $(C E O P, 1$, if $C E O$ and Chair are the same person, otherwise 0$)$; board member meeting frequency (BMMF, the total number of board meetings held in one year); state-owned enterprises ( $S O E$, a dichotomous variable equal to 1 , if the state or government control firm); firm age (FA, the total number of listing years on the stock market). Firm size (FS, total assets natural log); leverage (Lev, the proportion of total debt to total assets); Big4 (Big4, a dichotomous variable equals 1 if a Big Four firm audited firm reports). ${ }^{* * *}, * *, *$ represents the level of significance at $1 \%, 5 \%$, and $10 \%$, respectively.

\subsection{Multivariate Analysis, Findings, and Discussion}

Table 4 shows the regression results to test $\mathrm{H} 1$ and $\mathrm{H} 2$. Model 1 shows the direct effect of firm performance on CSR reporting, and the coefficient of FP is significant $(p<0.05)$. The result supports $\mathrm{H} 1$ and the finding suggests that overall firm performance is positively related to CSR reporting. We extended our analysis a step further to test whether high performing firms and low performing firms affect CSR reporting. The coefficient of HPF is also positively significant in model $2(p<0.05)$, indicating that firm performance at the higher threshold results in greater CSR reporting and supports $\mathrm{H} 2$. The coefficient of $L P F$ is significantly negative in model $3(p<0.1)$, representing that mean worse-performing firms undertake less CSR reporting. Our results are in line with prior studies $[9,10,26,27]$ and support slack resources and legitimacy theories.

The state still performs the leading position in large listed companies, which is characteristic of the market in China $[9,46]$. However, private equity also increasingly attained prominence by increasing shareholding in these companies [9]. The regression results explicate that the percentage of the state's holdings has a positive impact on CSR reporting across all research models. This confirms that the state's market regulation role, especially in the context of cultural differences, as well as the legal system, is not close to that of western countries.

Our results are supported by slack resources theory from the perspective that in spite of the pressure from the Chinese government to undertake CSR business activities, CSR reporting is impacted by other factors in China. One of these key factors is the availability of financial resources to undertake CSR activities and reporting. As Liu and Eng [47] have identified, enterprises with better performance are more likely to disclose their CSR efforts. In spite of requirements by the central government to undertake CSR activities, China is still at an early stage regarding CSR reporting as a large number of the companies are not clear about, firstly, what CSR actions to undertake and, secondly, what CSR activities to report on [24]. 
From the legitimacy perspective, the social contract ideology would imply that companies need to undertake CSR and report on it [48], and the Chinese government also recognizes this. This CSR reporting legitimacy measure is currently recognized and implemented by large Chinese corporations (by financial performance) at present. As CSR reporting is in its infancy in China, it will take time for more sophisticated CSR reporting to occur for all companies, regardless of their financial status. For now, better-performing companies are providing more CSR reporting. This will change over the next few years as more companies will respond to societal demands (from stakeholders) and government pressure by endorsing reporting on social and environmental performance [48]. The question that remains from the stakeholder theory perspective is the degree of influence which various stakeholders have, and will have in the future, regarding CSR performance and reporting in China.

The results of the study send an imperative flag to the different partners with whom firms are associated. The first investors are able to identify profitable firms through the coverage of CSR reporting. Second, institutional shareholders are able to obtain the determinants of CSR reporting obtain better implementation of reporting guidelines. Lastly, other partners, like workers, NGOs, and customers are educated on the positive activities of the firms in connection to corporate partners.

Table 4. Firm performance and CSR reporting.

\begin{tabular}{|c|c|c|c|c|c|c|}
\hline \multicolumn{7}{|l|}{ Dependent Variable: CSR } \\
\hline \multirow[t]{2}{*}{ Variable } & \multicolumn{2}{|c|}{ Model 1: Full Sample } & \multicolumn{2}{|c|}{ Model 2: Sub-Sample } & \multicolumn{2}{|c|}{ Model 3: Sub-Sample } \\
\hline & Coef & $p$-Value & Coef & $p$-Value & Coef & $p$-Value \\
\hline$F P(T Q)$ & $0.0032^{* * *}$ & 0.012 & - & - & - & - \\
\hline$H F P(\widetilde{T Q})$ & - & - & $0.0037 * *$ & 0.014 & - & - \\
\hline $\operatorname{LFP}(T Q)$ & - & - & - & - & $-0.0050 *$ & 0.073 \\
\hline BS & -0.0007 & 0.947 & 0.0026 & 0.17 & -0.0014 & 0.269 \\
\hline CEOP & $-0.0147 * *$ & 0.011 & -0.0049 & 0.532 & $-0.0250 * * *$ & 0.004 \\
\hline$B M M F$ & -0.0002 & 0.64 & -0.0004 & 0.996 & -0.0003 & 0.532 \\
\hline$S O E$ & $0.0108^{* *}$ & 0.033 & $0.0135 *$ & 0.076 & 0.0072 & 0.302 \\
\hline$F A$ & $0.0007 *$ & 0.079 & $0.0013^{* *}$ & 0.029 & -0.0002 & 0.705 \\
\hline FS & $0.0060^{* * *}$ & 0.005 & $0.0105^{* * *}$ & 0.006 & $0.0050 *$ & 0.094 \\
\hline Lev & 0.0014 & 0.916 & 0.0106 & 0.588 & -0.0019 & 0.926 \\
\hline Big4 & $0.0152 * *$ & 0.028 & 0.0144 & 0.227 & $0.0184 * *$ & 0.03 \\
\hline Constant & $1.061^{* * *}$ & 0 & $0.9710^{* * *}$ & 0 & $1.101^{* * *}$ & 0 \\
\hline Industry EYear Dummies & \multirow{2}{*}{\multicolumn{2}{|c|}{$\begin{array}{c}\text { YES } \\
0.1408\end{array}$}} & \multicolumn{2}{|c|}{ YES } & \multicolumn{2}{|c|}{ YES } \\
\hline$R^{2}$ & & & \multicolumn{2}{|c|}{0.119} & \multicolumn{2}{|c|}{0.1806} \\
\hline$N$ & \multicolumn{2}{|c|}{4257} & \multicolumn{2}{|l|}{2177} & \multicolumn{2}{|c|}{2080} \\
\hline
\end{tabular}

Model (1)-(3) are the OLS regression models of which dependent variable is CSR and measured by CSR index by using a dichotomous procedure, one if an item disclosed and 0 if it not. Firm performance is measured by Tobin's $Q$ (Market capitalization of total assets minus equity book value minus deferred tax liability divided by total assets). Board size (BS, the total number of directors on the board); $C E O$ power (CEOP, 1, if CEO and Chair are the same person, otherwise 0 ); board member meeting frequency (BMMF, the total number of board meetings held in one year); state-owned enterprises (SOE, a dichotomous variable equal to 1, if the state or government control firm); firm age (FA, the total number of listing years on the stock market); firm size (FS, total assets natural log); leverage (Lev, the proportion of total debt to total assets); Big4 (Big4, a dichotomous variable equals 1 if a Big Four firm audited firm reports). ${ }^{* * *}, * *, *$ represents the level of significance at $1 \%, 5 \%$, and $10 \%$, respectively.

\subsection{Robustness Tests}

\subsubsection{Alternative Measure of Firm Performance}

To ensure the robustness of our finding, we used the alternative measure of firm performance, and we replaced Tobin's $Q$ with $R O A$, which is measured by net profit divided by total assets. The results for the alternative measures reported in Table 5. The coefficient of $F P$ remains significant in model $1(p<0.05)$. The coefficient of HPF remains positively significant in model $2(p<0.1)$, and the coefficient of $L P F$ remains negative and significant in model $3(p<0.05)$. These findings are consistent with our previous findings reported in Table 4. 
Table 5. Robustness checks: alternative measure of firm performance.

\begin{tabular}{|c|c|c|c|c|c|c|}
\hline \multicolumn{7}{|l|}{ Dependent Variable: CSR } \\
\hline \multirow[t]{2}{*}{ Variable } & \multicolumn{2}{|c|}{ Model 1: Full Sample } & \multicolumn{2}{|c|}{ Model 2: Sub-Sample } & \multicolumn{2}{|c|}{ Model 3: Sub-Sample } \\
\hline & Coef & $p$-Value & Coef & $p$-Value & Coef & $p$-Value \\
\hline$F P(R O A)$ & $0.0644^{* *}$ & 0.011 & - & - & - & - \\
\hline$H F P(R O A)$ & - & $\longrightarrow$ & $0.1581^{* *}$ & 0.07 & - & $\longrightarrow$ \\
\hline $\operatorname{LFP}(R O A)$ & - & $\longrightarrow$ & - & & $-0.1352 * *$ & 0.024 \\
\hline BS & -0.0007 & 0.947 & 0.0002 & 0.89 & 0.0006 & 0.705 \\
\hline CEOP & $-0.0168^{* * *}$ & 0.004 & $-0.0223 * *$ & 0.016 & $-0.0149^{* *}$ & 0.049 \\
\hline$B M M F$ & -0.0003 & 0.512 & -0.001 & 0.156 & 0.0001 & 0.89 \\
\hline$S O E$ & $0.0154^{* * *}$ & 0.003 & $0.0244^{* * *}$ & 0.001 & 0.0061 & 0.402 \\
\hline$F A$ & 0.0002 & 0.536 & -0.0008 & 0.903 & $0.0011^{* *}$ & 0.053 \\
\hline FS & $0.00360 *$ & 0.091 & -0.0026 & 0.381 & $0.0136^{* * *}$ & 0 \\
\hline Lev & 0.0001 & 0.992 & $0.0380 *$ & 0.078 & $-0.0441 *$ & 0.024 \\
\hline Big4 & $0.0206^{* * *}$ & 0.004 & $0.0270 * *$ & 0.01 & $0.0181 *$ & 0.059 \\
\hline Constant & $1.178^{* * *}$ & 0 & $1.300^{* * *}$ & 0 & $1.015^{* * *}$ & 0 \\
\hline Industry EYear Dummies & & \multicolumn{2}{|c|}{ YES } & \multicolumn{2}{|c|}{ YES } \\
\hline$R^{2}$ & \multicolumn{2}{|c|}{0.0943} & \multicolumn{2}{|c|}{0.0935} & \multicolumn{2}{|c|}{0.1279} \\
\hline$N$ & \multicolumn{2}{|c|}{4257} & \multicolumn{2}{|c|}{2071} & \multicolumn{2}{|c|}{2186} \\
\hline
\end{tabular}

Model (1)-(3) are the OLS regression models of which dependent variable is CSR and measured by the CSR index by using a dichotomous procedure, one if an item disclosed and 0 if it not. Firm performance is measured by ROA (net profit divided by total assets). Board size (BS, the total number of directors on the board); CEO power $(C E O P, 1$, if $C E O$ and Chair are the same person, otherwise 0$)$; board member meeting frequency ( $B M M F$, the total number of board meetings held in one year); state-owned enterprises ( $S O E$, a dichotomous variable equal to 1, if the state or government control firm); firm age (FA, the total number of listing years on the stock market); firm size (FS, total assets natural log); leverage (Lev, the proportion of total debt to total assets); Big4 (Big4, a dichotomous variable equals 1 if a Big Four firm audited firm reports). ${ }^{* * *}, * *, *$ represents the level of significance at $1 \%, 5 \%$, and $10 \%$, respectively.

\subsubsection{Controlling the Endogeneity Issue}

To deal with the endogeneity problem, we use two different models. First, we use one-year lagged of firm performance in the regression because the performance of the company need time before they have any influence on the CSR reporting decisions. Models 1, 2, and 3 of Table 6 demonstrate the findings of lagged measures. The outcomes for the lagged measures of firm performance variables remain consistent with our main results in Table 4. Second, we used two-stage least squares (TSLS) regression to address the endogeneity problem and used one year lagged measure of firm performance as an instrumental variable. Models 4, 5, and 6 of Table 6 show the findings of TSLS and our results are, again, the same with the main findings. 
Table 6. Endogeniety tests.

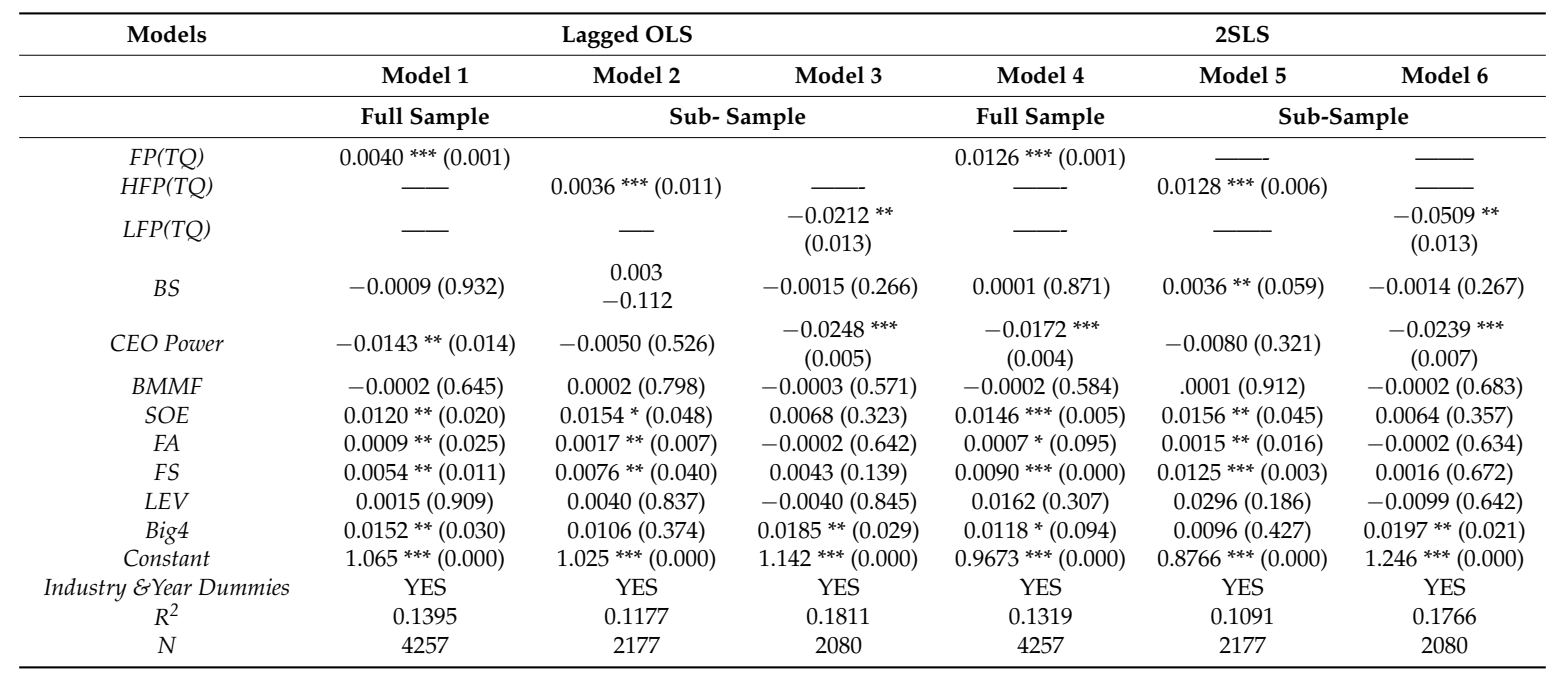

Model (1)-(3) are the Lagged OLS regression models and Model (4)-(6) are the 2SLS of which the dependent variable is CSR measured by the CSR index by using a dichotomous procedure, one if an item disclosed and 0 if it not. Firm performance is measured by Tobin's $Q$ (Market capitalization of total assets minus equity book value minus deferred tax liability divided by total assets). Board size (BS, the total number of directors on the board). CEO power $(C E O P, 1$, if $C E O$ and Chair are the same person, otherwise 0$)$; board member meeting frequency (BMMF, the total number of board meetings held in one year); state-owned enterprises ( $S O E$, a dichotomous variable equal to 1 , if the state or government control firm); firm age (FA, the total number of listing years on the stock market); firm size (FS, total assets natural log); leverage (Lev, the proportion of total debt to total assets); Big4 (Big4, a dichotomous variable equals 1 if a big four firm audited firm reports). ${ }^{* * *},{ }^{* *},{ }^{*}$ represents the level of significance at $1 \%, 5 \%$, and $10 \%$, respectively.

\section{Conclusions}

We have explored the effect of firm performance on CSR reporting through the lens of the stakeholder, slack resources, and legitimacy theories. Evidence indicates that firm performance has a significant influence on CSR reporting and, specifically, firms with better performance report more on CSR activities than those with lower performance. Our findings remain the same after controlling for the problem of endogeneity. Our results have implications for the development of CSR reporting in developing countries, like China: that financially-solid performing companies undertake more CSR reporting. With increasing stakeholder pressure more companies are bound to undertake CSR activities and reporting.

Research tends to understand CSR reporting in a variety of settings. CSR reporting supports investors in obtaining non-financial information beyond the company's financial statements. For regulators, the level of presentation and disclosure of CSR reporting serves as a "signal" to implement or change legislation which impacts CSR activities and reporting.

This study has highlighted the state of influence on CSR reporting of Chinese companies in the current context. Our results have confirmed that CSR reporting is a legitimacy tool for better financially-performing companies in China. This is in spite of the government pressure to undertake CSR activities and reporting. The main problem that Chinese companies face at present is confusion. As CSR activities and reporting are in infancy, Chinese companies are not very confident regarding CSR focus. From a legitimacy angle, we propose that Chinese companies should allow stakeholders (in addition to the government), such as employees, customers, media, and NGOs, to determine the key areas of concern and improvement for different Chinese companies to consider. Chinese companies should also use CSR reporting to determine key areas that require their attention. In other words, Chinese companies should use CSR reporting as an internal audit tool to determine their CSR agenda. Our paper has some limitations. First, we concentrated on the overall CSR index. A detailed analysis of various forms of CSR and their stakeholder impacts can be undertaken in the future. Future studies should apply the specific CSR disclosures, such as environment and sustainability 
disclosures; disclosures on the protection of employee and customer interests, disclosures on the protection of shareholder interests, and other CSR techniques, like content analysis, such as the number of words, sentences, paragraphs, or other methods. Secondly, this research is restricted to firm performance indicators, like Tobin's $Q$, to measure firm financial performance. The future investigation could apply more firm performance indicators (both accounting-based and market-based performance, e.g., stock return, and price earnings ratio) to explore the correlation between firm performance and CSR reporting.

Author Contributions: The manuscript was written through collective contributions from all authors. Conceptualization, Methodology, Formal analysis, M.S.S. and Z.C.; Writing—original draft, M.S.S.; Investigation, M.S.S.; Z.C., N.V.K., T.K. and M.U.; Supervision, Z.C.; Writing-review \& editing, M.S.S., Z.C., N.V.K., T.K. and M.U. All authors have given approval to the final version of the manuscript.

Acknowledgments: This paper is supported by Research on the Constructing Performance Evaluation of Chinese High-tech Listed Companies (Ref. 2013GX4D133).

Conflicts of Interest: The authors declare no conflict of interest.

\section{References}

1. Dhaliwal, D.S.; Li, O.Z.; Tsang, A.; Yang, Y.G. Voluntary nonfinancial disclosure and the cost of equity capital: The initiation of corporate social responsibility reporting. Acc. Rev. 2011, 86, 59-100. [CrossRef]

2. Margolis, J.D.; Walsh, J.P. Misery loves companies: Rethinking social initiatives by business. Admin. Sci. Q. 2003, 48, 268-305. [CrossRef]

3. Orlitzky, M.; Schmidt, F.L.; Rynes, S.L. Corporate social and financial performance: A meta-analysis. Organ. Stud. 2003, 24, 403-441. [CrossRef]

4. Hooghiemstra, R. Corporate communication and impression management-new perspectives why companies engage in corporate social reporting. J. Bus. Ethics 2000, 27, 55-68. [CrossRef]

5. Blasi, S.; Caporin, M.; Fontini, F. A multidimensional analysis of the relationship between corporate social responsibility and firms' economic performance. Ecol. Econ. 2018, 147, 218-229. [CrossRef]

6. Makanyeza, C.; Chitambara, T.L.; Kakava, N.Z. Does corporate social responsibility influence firm performance? Empirical evidence from harare, zimbabwe. J. Afr. Bus. 2018, 19, 155-173. [CrossRef]

7. Agyemang, O.S.; Ansong, A. Corporate social responsibility and firm performance of ghanaian smes: Mediating role of access to capital and firm reputation. J. Glob. Responsib. 2017, 8, 47-62. [CrossRef]

8. Amini, C.; Dal Bianco, S. Corporate social responsibility and latin american firm performance. Corp. Gov. Int. J. Bus. Soc. 2017, 17, 403-445. [CrossRef]

9. Li, Q.; Luo, W.; Wang, Y.; Wu, L. Firm performance, corporate ownership, and corporate social responsibility disclosure in China. Bus. Ethics Eur. Rev. 2013, 22, 159-173. [CrossRef]

10. Choi, J.-S.; Kwak, Y.-M.; Choe, C. Corporate social responsibility and corporate financial performance: Evidence from korea. Aust. J. Manag. 2010, 35, 291-311. [CrossRef]

11. Jamali, D. A stakeholder approach to corporate social responsibility: A fresh perspective into theory and practice. J. Bus. Ethics 2008, 82, 213-231. [CrossRef]

12. Gray, R.; Javad, M.; Power, D.M.; Sinclair, C.D. Social and environmental disclosure and corporate characteristics: A research note and extension. J. Bus. Financ. Acc. 2001, 28, 327-356. [CrossRef]

13. Cormier, D.; Magnan, M.; Van Velthoven, B. Environmental disclosure quality in large german companies: Economic incentives, public pressures or institutional conditions? Eur. Acc. Rev. 2005, 14, 3-39. [CrossRef]

14. Reverte, C. Determinants of corporate social responsibility disclosure ratings by spanish listed firms. J. Bus. Ethics 2009, 88, 351-366. [CrossRef]

15. Surroca, J.; Tribó, J.A.; Waddock, S. Corporate responsibility and financial performance: The role of intangible resources. Strateg Manag. J. 2010, 31, 463-490. [CrossRef]

16. Cahan, S.F.; De Villiers, C.; Jeter, D.C.; Naiker, V.; Van Staden, C.J. Are csr disclosures value relevant? Cross-country evidence. Eur. Acc. Rev. 2016, 25, 579-611. [CrossRef]

17. Tang, Z.; Tang, J. Stakeholder-firm power difference, stakeholders' csr orientation, and smes' environmental performance in China. J. Bus. Ventur. 2012, 27, 436-455. [CrossRef] 
18. Guo, J.; Sun, L.; Li, X. Corporate social responsibility assessment of chinese corporations. Int. J. Bus. Manag. 2009, 4, 54. [CrossRef]

19. Jensen, M.C.; Meckling, W.H. Theory of the firm: Managerial behavior, agency costs and ownership structure. J. Financ. Econ. 1976, 3, 305-360. [CrossRef]

20. Donaldson, T.; Preston, L.E. The stakeholder theory of the corporation: Concepts, evidence, and implications. Acad. Manag. Rev. 1995, 20, 65-91. [CrossRef]

21. Price, J.M.; Sun, W. doing good and doing bad: The impact of corporate social responsibility and irresponsibility on firm performance. J. Bus. Res. 2017, 80, 82-97. [CrossRef]

22. Amato, L.H.; Amato, C.H. The effects of firm size and industry on corporate giving. J. Bus. Ethics 2007, 72, 229-241. [CrossRef]

23. De Villiers, C.; Van Staden, C.J. Can less environmental disclosure have a legitimising effect? Evidence from Africa. Acc. Organ. Soc. 2006, 31, 763-781. [CrossRef]

24. Zhu, Q.; Liu, J.; Lai, K.-H. Corporate social responsibility practices and performance improvement among chinese national state-owned enterprises. Int. J. Prod. Econ. 2016, 171, 417-426. [CrossRef]

25. Noronha, C.; Tou, S.; Cynthia, M.; Guan, J.J. Corporate social responsibility reporting in china: An overview and comparison with major trends. Corp. Soc. Responsib. Environ. Manag. 2013, 20, 29-42. [CrossRef]

26. Nelling, E.; Webb, E. Corporate social responsibility and financial performance: The "virtuous circle" revisited. Rev. Quant. Financ. Acc. 2009, 32, 197-209. [CrossRef]

27. Zu, L.; Song, L. Determinants of managerial values on corporate social responsibility: Evidence from China. J. Bus. Ethics 2009, 88, 105-117. [CrossRef]

28. Gray, R.; Bebbington, J. Corporate sustainability, accountability and the pursuit of the impossible dream. Handb. Sustain. Dev. 2007, 23, 376-394.

29. Van der Laan Smith, J.; Adhikari, A.; Tondkar, R.H. Exploring differences in social disclosures internationally: A stakeholder perspective. J. Acc. Public Policy 2005, 24, 123-151. [CrossRef]

30. Union of Concerned Scientists. UCS Satellite Database; Union of Concerned Scientists: Cambridge, MA, USA, 2017.

31. Cho, C.H.; Patten, D.M. The role of environmental disclosures as tools of legitimacy: A research note. Acc. Organ. Soc. 2007, 32, 639-647. [CrossRef]

32. $\mathrm{Ng}$, E.J.; Koh, H.C. An agency theory and probit analytic approach to corporate non-mandatory disclosure compliance. Asia-Pac. J. Acc. 1994, 1, 29-44. [CrossRef]

33. Roberts, R.W. Determinants of corporate social responsibility disclosure: An application of stakeholder theory. Acc. Organ. Soc. 1992, 17, 595-612. [CrossRef]

34. Haniffa, R.M.; Cooke, T.E. The impact of culture and governance on corporate social reporting. J. Acc. Public Policy 2005, 24, 391-430. [CrossRef]

35. Alnajjar, F.K. Determinants of social responsibility disclosures of us fortune 500 firms: An application of content analysis. In Advances in Environmental Accounting \& Management; Emerald Group Publishing Limited: Bingley, UK, 2000; pp. 163-200.

36. Neu, D.; Warsame, H.; Pedwell, K. Managing public impressions: Environmental disclosures in annual reportsa. Acc. Organ. Soc. 1998, 23, 265-282. [CrossRef]

37. Ghelli, C. Corporate Social Responsibility and Social Performance: An Empirical Evidence; Copenhagen Business School: Frederiksberg, UK, 2013.

38. Gamerschlag, R.; Möller, K.; Verbeeten, F. Determinants of voluntary csr disclosure: Empirical evidence from Germany. Rev. Manag. Sci. 2011, 5, 233-262. [CrossRef]

39. Tagesson, T.; Blank, V.; Broberg, P.; Collin, S.O. What explains the extent and content of social and environmental disclosures on corporate websites: A study of social and environmental reporting in swedish listed corporations. Corp. Soc. Responsib. Environ. Manag. 2009, 16, 352-364. [CrossRef]

40. Jiraporn, P.; Jumreornvong, S.; Jiraporn, N.; Singh, S. How do independent directors view powerful ceos? Evidence from a quasi-natural experiment. Financ. Res. Lett. 2016, 16, 268-274. [CrossRef]

41. Khan, W.A.; Vieito, J.P. Ceo gender and firm performance. J. Econ. Bus. 2013, 67, 55-66. [CrossRef]

42. Ahmed Haji, A. Corporate social responsibility disclosures over time: Evidence from Malaysia. Manag. Audit. J. 2013, 28, 647-676. [CrossRef]

43. Wang, Z.; Wang, N.; Liang, H. Knowledge sharing, intellectual capital and firm performance. Manag. Decis. 2014, 52, 230-258. [CrossRef] 
44. Usman, M.; Zhang, J.; Farooq, M.U.; Makki, M.A.M.; Dong, N. Female directors and ceo power. Econ. Lett. 2018, 165, 44-47. [CrossRef]

45. Gujarati, D.N. Basic Econometrics; Tata McGraw-Hill Education: New York, NY, USA, 2009.

46. Zheng, L.; Balsara, N.; Huang, H. Regulatory pressure, blockholders and corporate social responsibility (CSR) disclosures in China. Soc. Responsib. J. 2014, 10, 226-245. [CrossRef]

47. Liu, G.; Eng, T.-Y.; Ko, W.-W. Strategic direction of corporate community involvement. J. Bus. Ethics 2013, 115, 469-487. [CrossRef]

48. Den Hond, F.; de Bakker, F.G.; Neergaard, P. Introduction to managing corporate social responsibility in action: Talking, doing and measuring. In Managing Corporate Social Responsibility in Action; Routledge: London, UK, 2016; pp. 15-26.

(C) 2018 by the authors. Licensee MDPI, Basel, Switzerland. This article is an open access article distributed under the terms and conditions of the Creative Commons Attribution (CC BY) license (http:/ / creativecommons.org/licenses/by/4.0/). 